\title{
Potential Palaeozoic Hydrocarbon Plays in and Around Peninsular Malaysia
}

\author{
Bernard J. Pierson, Askury A.Kadir, Chow Weng Sum \& Zuhar Z.T. Harith \\ (Universiti Teknologi PETRONAS)
}

Paleozoic sedimentary deposits are exposed in several locations on Peninsular Malaysia and may contain all the elements of a hydrocarbon system. Initial observations, mainly in the Kinta Valley, suggest the presence of source rocks, reservoirs and seals within the Paleozoic interval. The limestone hills of the Kinta Valley were the initial focus of this research project. The hills are remnants of extensive limestone beds, which are part of a very large Paleozoic carbonate complex that covered large parts of South-East Asia. The limestone beds are interbedded with sandstone, siltstone and carbonaceous shale over a thickness of up to $3000 \mathrm{~m}$.

Several layers of black carbonaceous shale, rich in organic matter are part of the clastic sequences and could constitute potential source rocks. Clay and shale layers within the clastic sequences will act as intraformational seals whereas the base Tertiary unconformity may have regional sealing capacity. The carbonate and the clastic sequences may contain potential reservoir intervals, either as sandstone layers or shallow marine limestones. An analysis of the limestone hills of the Kinta Valley has led to a schematic reconstruction of facies distribution for the Permian carbonate complex that suggests that reservoirs could be found in the eastern part and off the eastern coast of Peninsular Malaysia. Outcrops in eastern Peninsular Malaysia confirm the presence of a shallow marine platform, with potential reservoir horizons, that probably extended eastwards, far into the China Sea.

Potential plays could include Palaeozoic limestone underlying the base Tertiary unconformity in the Malay Basin. Two wells drilled below the Base Tertiary unconformity east of Peninsular Malaysia, penetrated Palaeozoic limestone but did not encounter hydrocarbons. It is likely that these wells were drilled to test Tertiary structures but Paleozoic structures may be offset from the Tertiary structures at these locations. Tertiary deposits lie unconformably above pre-Tertiary sequences, which have undergone considerable structural deformation prior to deposition and folding of Tertiary deposits. Paleozoic structures would therefore be, to a large extent, independent from younger Tertiary structures.

Structural and possibly stratigraphic traps and even "buried hills" traps, so far untested in Malaysia, probably exist east of Peninsular Malaysia and in the Malay Basin. The existing 2D seismic coverage of the Malay Basin provides hints of pre-Tertiary structures but an unambiguous identification of these potential traps is, unfortunately, hampered by the poor seismic imaging below the Base Tertiary unconformity.

The clastic sequences comprise sandstone layers that could form potentially good reservoirs. The sandstone beds exposed at Seri Iskandar make up more than 50\% of the entire exposed sequence and their total thickness probably exceeds 400 meters. The lateral extent of these deposits is, however, unknown. Should the clastic sequence represent a lowstand wedge, with the sandstone beds representing turbidites, it would mostly be confined to the western part of Peninsular Malaysia, and potential hydrocarbon plays could be found in the Strait of Melaka.

Establishing a reliable bio- and litho-stratigraphic framework, establishing the facies distribution of Palaeozoic deposits and resolving seismic imaging in pre-Tertiary deposits are the key challenges in future exploration of Paleozoic plays. 